\title{
Improving Environmental Loading Assessments of Cry Protein from GM Plants Based on Experimentation in Cotton
}

\author{
Oliver G. G. Knox ${ }^{\mathrm{a}, \mathrm{d}, \mathrm{e}}$, Vadakattu V.S.R. Gupta ${ }^{*}, \mathrm{~b}, \mathrm{~d}$, Grant N. Roberts ${ }^{\mathrm{c}}$ and Sharon J. Downes ${ }^{\mathrm{a}, \mathrm{d}}$
}

${ }^{a}$ CSIRO Entomology, Locked Bag 59, Narrabri, NSW 2390, Australia

${ }^{b}$ CSIRO Entomology, PMB \#2, Glen Osmond, SA 5064, Australia

${ }^{c}$ CSIRO Plant Industry, Locked Bag 59, Narrabri, NSW 2390, Australia

${ }^{d}$ Cotton Catchment Communities CRC, Locked bag 1001, Narrabri, NSW 2390, Australia

${ }^{e}$ Scottish Agricultural College, Kings Buildings, Edinburgh, EH9 3JG, Scotland

\begin{abstract}
Transgenic Bt-cotton expresses insecticidal Cry proteins via Cry genes, introduced from the soil bacterium Bacillus thuringiensis (Bt). Data on levels of Cry proteins expressed in transgenic Bt-crops is important for assessing levels of environmental exposure. During investigations into the rhizosphere impacts of Cry proteins from GM cotton we found that CrylAc expression throughout the season was significantly lower in roots of glasshouse-reared cotton plants (average of $0.03 \mu \mathrm{g} / \mathrm{g}$ in the roots) compared to the same Bt-cotton varieties grown in the field $(0.14 \mu \mathrm{g} / \mathrm{g}$ in the roots). We subsequently undertook a whole plant field assessment of both CrylAc and Cry $2 A b$ expression in stem, leaves, root, and flowers, squares and bolls of Australian cotton varieties Sicot 289 Bollgard ${ }^{\circledR}$ II (289B) and Sicot 289 Bollgard ${ }^{\circledR}$ II Roundup Ready (289BR) over an entire season. Significant differences in the expression levels of CrylAc versus Cry2Ab occurred in the whole plant throughout the season. CrylAc levels remained relatively constant at an average of $6.1 \mu \mathrm{g} / \mathrm{g}$ whilst $C r y 2 A b$ levels averaged $29.0 \mu \mathrm{g} / \mathrm{g}$, but decreased over time. Analysis of whole plant expression levels, plant stand densities, and aspects of crop management, estimated that levels of CrylAc and Cry $2 A b$ deposited in the soil at the end of the season were 0.26 and $0.16 \mu \mathrm{g} / \mathrm{g}$ soil, respectively. The undertaken experiments highlight that assessments of environmental loading of proteins from GM plants would be improved with the use of field grown plants, whole plant assessments, increased knowledge on fate and persistence of GM proteins in the soil, and refinement of current ELISA methodologies.
\end{abstract}

Keywords: Cotton, CrylAc, Cry2Ab, Bollgard ${ }^{\circledR}$ II, expression, Bacillus thuringiensis, field grown, Helicoverpa armigera, ELISA.

\section{INTRODUCTION}

Reliable estimates of transgenic protein expression in genetically modified (GM) crops can provide a valuable tool in assisting with understanding the development and management of resistance, non-target implications, economic performance and environmental loading of the transgenic proteins [1-3]. GM cotton, Gossypium hirsutum, expressing the insecticidal CrylAc gene, from the soil bacterium Bacillus thuringiensis (Bt), was introduced commercially in Australia in 1996 [4]. The main target for this GM product was control of Helicoverpa armigera, which demonstrated ability to develop resistance to CrylAc under a laboratory imposed selection regime [5]. These observations, in addition to a reported decline in CrylAc expression in cotton over a season $[6,7]$, suggested that the risk of $H$. armigera evolving resistance to a single Cry protein Bt crop in Australia was high.

BollgardII $^{\circledR}$ varieties that expressed both CrylAc and $C r y 2 A b$ [8] were introduced in the 2003/04 season. Capped

*Address correspondence to this author at the CSIRO Entomology, PMB \#2, Glen Osmond, SA 5064, Australia; Tel: +61 (0) 88303 8579;

E-mail: gupta.vadakattu@csiro.au limits for BollgardII ${ }^{\circledR}$ crops were initially imposed at $40 \%$, but were removed in $2004 / 05$ on the provision that a resistance management plan (RMP) was followed [9, 10]. Under good RPM practises, conditions for potential resistance development is considered to be retarded, providing that Cry expression remains at levels high enough to exert insecticidal control [11-13]. However, there have been concerns that over expression of the GM material could have implications for non-target organisms and increased environmental loading of these proteins. Numerous evaluations have indicated that there is no risk to the health of non-target organisms [14-17], but these studies were conducted without simultaneous measurement of Cry expression levels in plants.

Bt plants may have the potential to influence the soil in which they are growing through the release of the Bt proteins in root exudates or from sloughed or decaying plant material $[18,19]$. Past work on whole plants suggests that rearing plants in a glasshouse environment can significantly impact on Cry expression [19] and aboveground expression levels may not truly reflect expression in roots. We set out to investigate $\mathrm{CrylAc}$ expression in cotton roots and to evaluate $\mathrm{Bt}$ expression levels in glasshouse versus field grown plant roots. Results from these studies indicated that CrylAc levels in below ground material from plants reared in the glass- 
house significantly underestimated expression levels in field grown plant populations. Subsequently, the focus of our work became the measurement of expression of both Cry proteins in above and below-ground field grown cotton.

We present information on relative variation in the expression of CrylAc and $C r y 2 A b$ in commercially available field-grown Australian cotton varieties throughout a growing season. Analysis of the crop stand and biomass, as well as management options used in preparation of soil for subsequent plantings, were used to conduct an assessment of the loading of soils with transgenic proteins at the end of the growing season.

The results of our experimentation are discussed with a view to offering suggestions on how methods of Cry protein assessment in tissues of GM plants could be improved in order to provide better estimations of environmental loading.

\section{MATERIAL AND METHODS}

\section{Preliminary Assessment of Glasshouse and Field Levels of Cry1Ac in Cotton Roots}

We used a quantitative ELISA method for the assessment of the Cry proteins to facilitate the throughput of high sample numbers and present a standardised level of expression comparison. In order to achieve this, plant material was sampled, processed and stored in such a way as to limit degradation of the Cry proteins [20] using available facilities and resources.

\section{Sampling of Glasshouse Material}

During July 2003, seven seeds each of cotton varieties Sicot 189 (189), Sicot 289-Bollgard ${ }^{\circledR}$ II (289B) and Sicot 289-Bollgard ${ }^{\circledR}$ II Roundup Ready (289BR) were planted in $30 \mathrm{~cm}$ diameter pots, containing $3 \mathrm{~kg}$ of a self mulching grey vertisol (53\% Clay, $0.75 \%$ organic carbon, $\mathrm{pH} 9.1$ ). Sicot 189 was included as a control, as it was the recurrent parent of the tested transgenic varieties. The pots were arranged in the glasshouse in a replicated random block design and a dripper watering system was used to irrigate the cotton daily to ensure that all pots received sufficient water so that moisture was not limiting. Root material was destructively sampled from pots at 42, 84 and 112 days after planting (DAP). Once recovered the roots were dehydrated in a Phoenix 200 (DEC International Inc, USA) at $55^{\circ} \mathrm{C}$ for four days, ground in a Type 843 coffee mill (Moulinex, France), and stored at $20^{\circ} \mathrm{C}$ until analysed.

\section{Sampling of Field Material}

During the 2003/04 season, four replicated blocks, each containing $189,289 \mathrm{~B}$ and $289 \mathrm{BR}$ in $8 \mathrm{~m}$ by four row plots, were established at the Myall Vale research centre in a soil with $55 \%$ Clay, $0.50 \%$ organic carbon, $\mathrm{pH} 8.6$. For comparison with the glasshouse material, individual 289B and 289BR plants were dug up with a fork from each replicated plot at 45 and 130 DAP. Roots were recovered, dehydrated and ground, using the methods described for glasshouse plants.

\section{Sample Preparation and Quantitative ELISA of Glass- house and Field Roots}

Glasshouse and field root samples were analysed on EnviroLogix (USA) CrylAb/CrylAc QuantiPlate kits, using the manufacturer's standards and according to their instructions. Tissue extraction of the CrylAc protein was carried out on a weighted $0.1 \mathrm{~g}$ sub sample of each milled root. This was extracted with $1 \mathrm{ml}$ of $1 \mathrm{x} \mathrm{EEB}$ in a microfuge tube by vortexing for 5 seconds before being imbibed for $4 \mathrm{~h}$ at $21^{\circ} \mathrm{C}$, prior to centrifugation at $5000 \mathrm{rcf}$ for 5 minutes. A $100 \mu \mathrm{L}$ sample of the supernatant was used for quantitative ELISA. Absorbance was read in a Benchmark Microplate Reader (Bio Rad, Australia) at $450 \mathrm{~nm}$, recorded using Microplate Manager 5.1 (Bio Rad, Australia) and transferred to Excel (Microsoft, USA) for analysis.

\section{Evaluation of Seasonal Levels of Cry1Ac and Cry2Ab in Field Grown Cotton}

\section{Sampling of Field Material}

To compare below and above ground expression of proteins, four replicated blocks, each containing 189, 289B and 289BR in $8 \mathrm{~m}$ by eight row plots, were established in 2004/05. For Cry expression analysis, plants were dug up with a fork throughout the season at 34, 54, 97, 137 and 193 days after planting (DAP), which was equivalent to 307,536 , 1081, 1678 and 2327 day degrees.

Plants were returned to the laboratory within an hour of recovery, partitioned into; leaves and petioles (L), stems and branches $(\mathrm{S})$, roots $(\mathrm{R})$, and if present a pooled group of flowers, squares and bolls (FSB). Fresh weight of each of these partitions was recorded. Stem and root material was cut into $2 \mathrm{~cm}$ lengths and bolls, when present, were cut open to facilitate rapid and thorough drying. Drying was carried out for four days in a forced air Hurricane dehydrator (Wessburg and Tulander Pty. Ltd., Australia) running at $45^{\circ} \mathrm{C}$. Dry weights were recorded and the tissues ground in a $1 \mathrm{~A}$ Benchmill (Rock Labs, New Zealand) for $40 \mathrm{sec}$. A subsample of the ground material was transferred to a $2 \mathrm{ml} \mathrm{mi-}$ crofuge tube, which was stored at $-20^{\circ} \mathrm{C}$ until analysed.

\section{Quantitative ELISA of Field Plant Tissue}

In 2004/05, CrylAc and Cry2Ab coated plates and ELISA reagents were sourced from Strategic Diagnostic Inc. (SDI, USA) and were used according to the manufacturer's instructions for quantitative analysis. For the CrylAc plates, a spore and crystal suspension of CrylAc from bacterial strain HD73 (Genesearch, Australia) was used as a standard. For the Cry $2 A b$ plates, a ground lyophilised Corn Powder, containing only Cry $2 \mathrm{Ab}$ (Monsanto Australia), was used.

The HD73 (Genesearch, Australia) spore and crystal suspension was supplied as a $62 \mathrm{mg} C r y l A c / m l$. A 1 in 10 dilution of HD73 was prepared in distilled water and stored at $20^{\circ} \mathrm{C}$ until required for use, when it was thawed and further diluted to provide standards with a calculated range of 7 to 620 PPB.

From $1 \mathrm{~g}$ of the lyophilised Corn Powder, $6.014 \mathrm{mg}$ of $\mathrm{Cry} 2 \mathrm{Ab}$ was extracted (Monsanto Australia) into $1 \mathrm{ml}$ of ELISA extraction buffer (EEB; EnviroLogix, USA) assuming $100 \%$ extraction efficiency and subsequently diluted further in EEB to prepare standards in the range of 0.3 to 300 PPB.

For the ELISA assay, ground dehydrated plant material was removed from the freezer and weighed into $0.1 \mathrm{~g}$ amounts in $1.5 \mathrm{ml}$ microfuge tubes to which $1 \mathrm{ml}$ of EEB 
was added, mixed using a Retsch MM300 (Retsch GmbH \& Co., Germany) for 30 seconds, imbibed for $2 \mathrm{~h}$ at $21^{\circ} \mathrm{C}$ before being centrifuged at $13200 \mathrm{rcf}$ for 5 minutes. For $C r y 2 A b$ analysis, $50 \mu \mathrm{L}$ of the supernatant was transferred to the ELISA plates for quantitative analysis. For CrylAc analysis an additional 1 in 10 dilution in EEB was required to bring the tissue CrylAc content within the detectable range, with $100 \mu \mathrm{L}$ of this diluted solution transferred to the ELISA plate.

After completion of all field ELISA assays, absorbance was read in a Benchmark Microplate Reader (Bio Rad, Australia) at $655 \mathrm{~nm}$ and handled as previously described.

\section{Environmental Loading of Cry Proteins}

For the end of season environment loading estimates the 193 DAP samples' quantitative Cry data and partitioned plant dry weight measurements were used to calculate partitioned tissue expression and total Cry protein levels for individual plants. Stand counts, of plants per metre within the sampled crop population, were taken over 118 individual metres of the crop. This data; stand count, plant biomass and expression levels were used to generate a weight of Cry gene expression per metre of crop. Post picking the crop was slashed and root pulled, prior to incorporation into the top 15 $\mathrm{cm}$ of the soil. This data was used to estimate the Cry protein levels incorporated back into the soil system with the slashed crop.

\section{Statistical Analysis}

Sample results were compiled, tabulated and statistically analysed using ANOVA with GenStat version 8 (VSN International Limited, UK). The variance ratio was considered to indicate a significant difference between factors when $P$ $<0.05$. Normality of the data was assessed from fitted plots of the residuals and none of the data required transformation.

Glasshouse assessment with ANOVA was initially undertaken with a combination of the measured factors; plant varietal traits (conventional, B and BR), environment (glass- house or field), time of sampling, and root partition (lateral or tap). Subset and individual factors where subsequently assessed with ANOVA.

In the whole plant field assessments the factors were; plant varietal traits (conventional, B and BR), plant partition (L, S, R and FSB) and time of sampling. These factors were initially interrogated in combination and then in subsets and as individuals. The sampled varieties position within the planting design of the field was added as a blocking structure to address the random effects of field location.

Regression curves, when mentioned in the text, were fitted to the data using SigmaPlot version 9 (SYSTAT Software Inc., USA).

\section{Results}

\section{Preliminary Assessment of Glasshouse and Field Levels of Cry1Ac in Cotton Roots}

CrylAc expression in roots of glasshouse plants declined from 0.069 to $0.003 \mu \mathrm{g} / \mathrm{g}$ over the 56 days, whilst CrylAc in field roots increased from 0.050 to $0.279 \mu \mathrm{g} / \mathrm{g}$ over the 85 days between the fist and last sampling (Fig. 1). Additionally, under glasshouse conditions levels of CrylAc expression in roots of $289 \mathrm{~B}$ were significantly lower than in 289 $\mathrm{BR}(P<0.001, \mathrm{n}=24)$ throughout the experiment.

Expression of CrylAc did not differ between lateral and tap roots recovered from glasshouse plants, with mean values of 0.147 and $0.162 \mu \mathrm{g} / \mathrm{g}$, respectively.

In field grown plants, 289BR had significantly higher levels of CrylAc than 289B $(P=0.036, \mathrm{n}=12)$ in assessed root material.

There were observable differences in the physiology of the roots of glasshouse versus field sampled plants. For example, glasshouse tap roots were thin and the pot soil was heavily proliferated by lateral roots, where as in field samples the tap root was thick with less prolific lateral roots recovered.

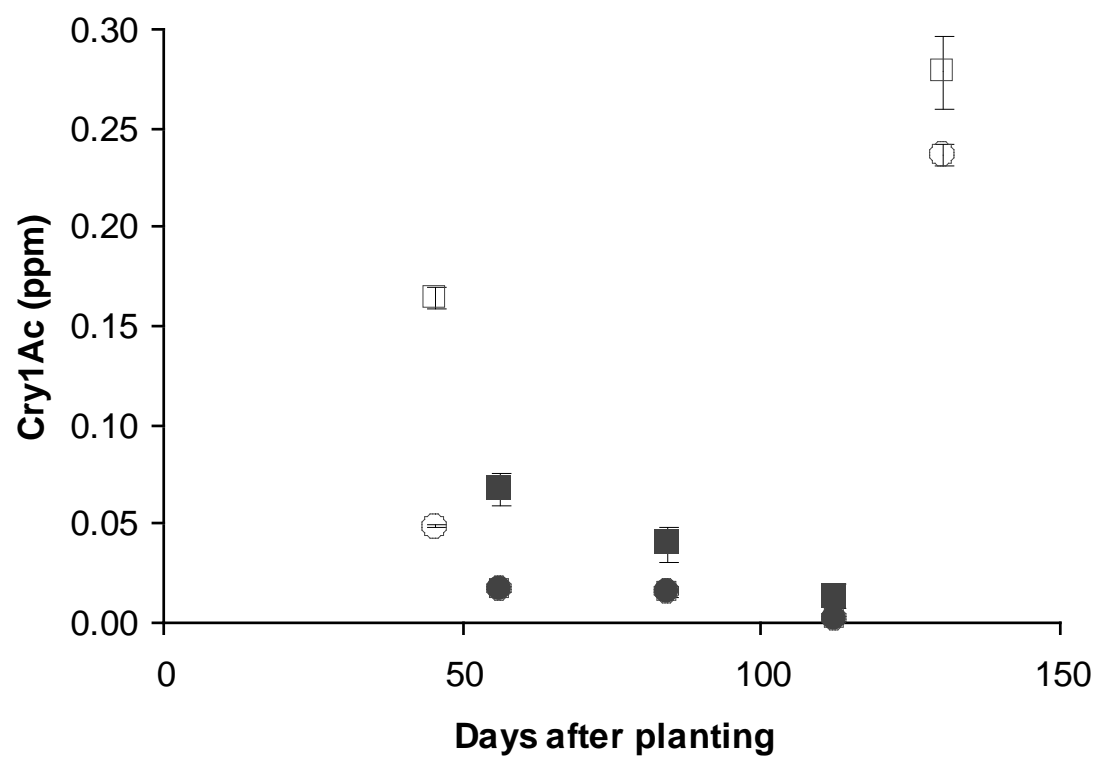

Fig. (1). Comparison of mean CrylAc levels from roots of field grown (open) and glasshouse (closed) Sicot 289B (circles) and Sicot 289BR (squares). Error bars represent the standard error of the means $(n=12)$. 


\section{Evaluation of Seasonal Levels of Cry1Ac and Cry2Ab in Field Grown Cotton}

Repeated assessment of HD73 as a CrylAc standard gave reproducible results over the range of 3 to $60 \mathrm{PPB}$, which followed a linear relationship $\left(y=617 x^{1.01}, R^{2}=0.91, \mathrm{n}=20\right)$. At higher concentrations, e.g. 100 and $600 \mathrm{PPB}$, increased variability in CrylAc detection occurred. Aliquots of the 1 in 10 dilution of HD73 were not affected by at least three cycles of freeze thawing (data not shown).

Ground corn powder (Monsanto, Australia), previously used in published ELISA and bioassay studies [21, 22], was found to produce a reliable standard over the range of 0.3 to 70 PPB $\left(y=-12.7 x^{2}+62.0 x+0.5, R^{2}=0.99, \mathrm{n}=15\right)$. However, it was found to be susceptible to freeze/thawing, thus aliquots and dilutions were prepared fresh when required. Substitution of EEB with water in the preparation of Cry2Ab standards resulted in ELISA plate detection over too narrow an absorbance range at $655 \mathrm{~nm}$ to be useful (data not shown).

During the 2004/05 season, analysis of the partitioned plants revealed that there was always a significant difference in recovered dry weights between the segregated plant tissues (in all cases $P<0.001$, data not shown) and that at cer- tain sampling points these differences also existed between 289B and 289BR $(P=0.036$ and 0.002 for comparisons between varieties at $3^{\text {rd }}$ and $5^{\text {th }}$ sampling, respectively, and $P<0.001$ in both cases for partition comparisons). These differences did not significantly affect final lint yield of 2929 and $3022 \mathrm{~kg} / \mathrm{ha}$ for the 289B and 289BR plots, respectively. Analysis of the partitioned tissues over the entire season showed a significant difference in Cry expression. CrylAc was significantly higher $(P=0.012)$ in the roots than in the leaves, but similar to stem and FSB whilst, in contrast, $C r y 2 A b$ expression was significantly less in the leaves and FSB $(P<0.001)$, but similar in roots and stem.

ELISA results from $0.1 \mathrm{~g}$ of dehydrated plant material were adjusted for actual plant partition weights and used to calculate Cry expression means for 289B and 289BR over the 2004/05 season (Fig. 2). This data indicated both expression pattern and level differences between CrylAc and Cry $2 A b$ within the assessed plant tissues. CrylAc levels in both cultivars generally increased toward the end of the season, whilst levels of Cry2Ab decreased after 97 DAP (Fig. 3). Expression levels in leaves and fruit flowers/squares/bolls (Fig. 4) followed a similar trend with equivalent levels of expression to those of the whole plant.
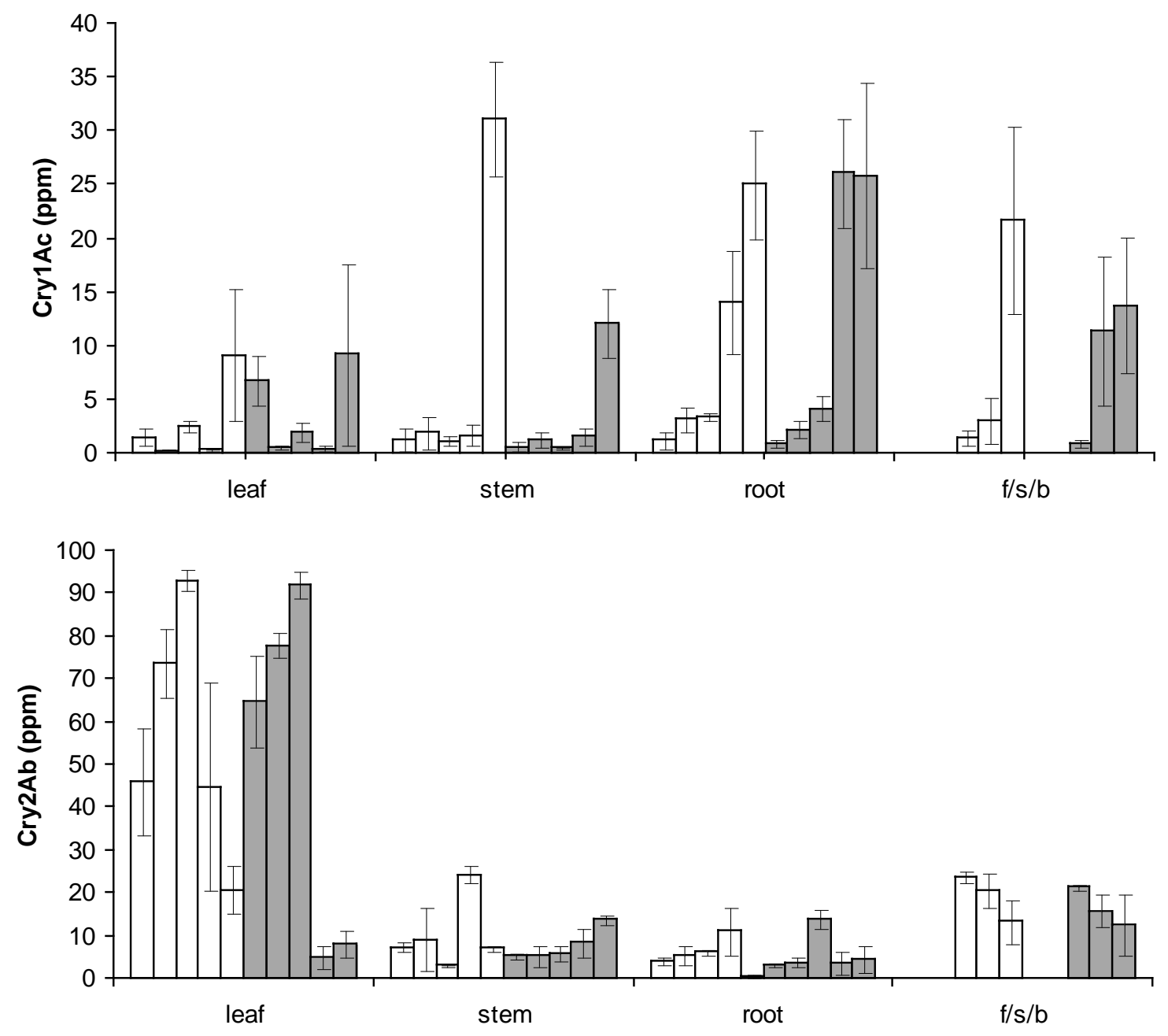

Fig. (2). PPM ( $\mu \mathrm{g} / \mathrm{g})$ measurements of CrylAc and Cry $2 A b$ in leaves, stem, root, and flowers/squares/bolls (f/s/b) of 289B (white) and 289BR (grey). Each tissue was measured at 5 times over the 2004/05 season at 34, 54, 97, 137 and 193 days (indicated as 1 to 5 on axis, respectively) after planting. The error bar represents the standard error of the means, based on a minimum of four partitioned plants. 


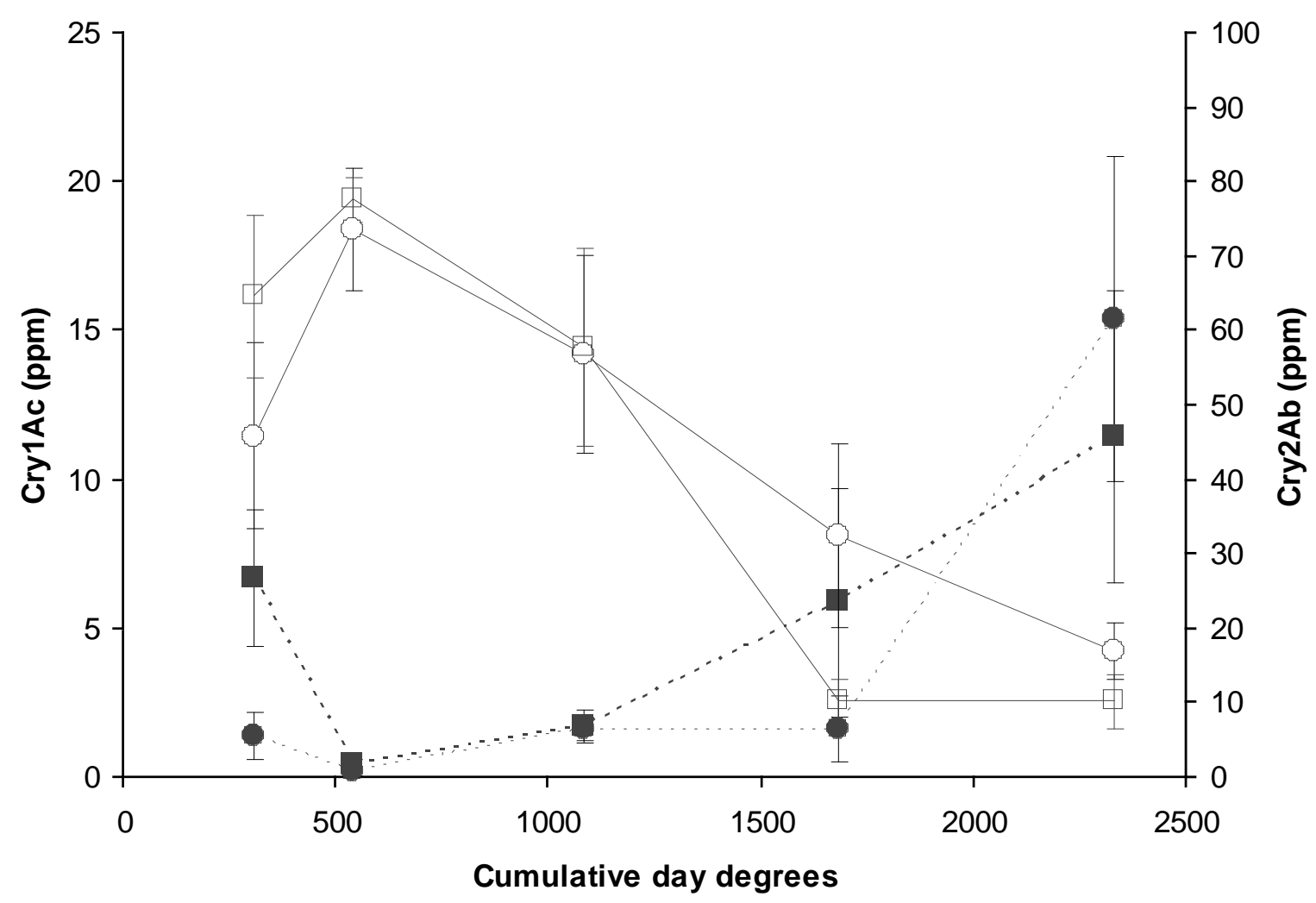

Fig. (3). Seasonal variation in the expression of CrylAc (closed) and Cry2Ab (open) in whole plants as analysed by ELISA of dehydrated field grown Sicot 289B (circles) and 289BR (squares). Means of analyses of 4 partitioned plants (representing 12 to 16 samples) at each point are presented. Error bars represent the standard error of the means. Time throughout the season is expressed as cumulative day degrees.

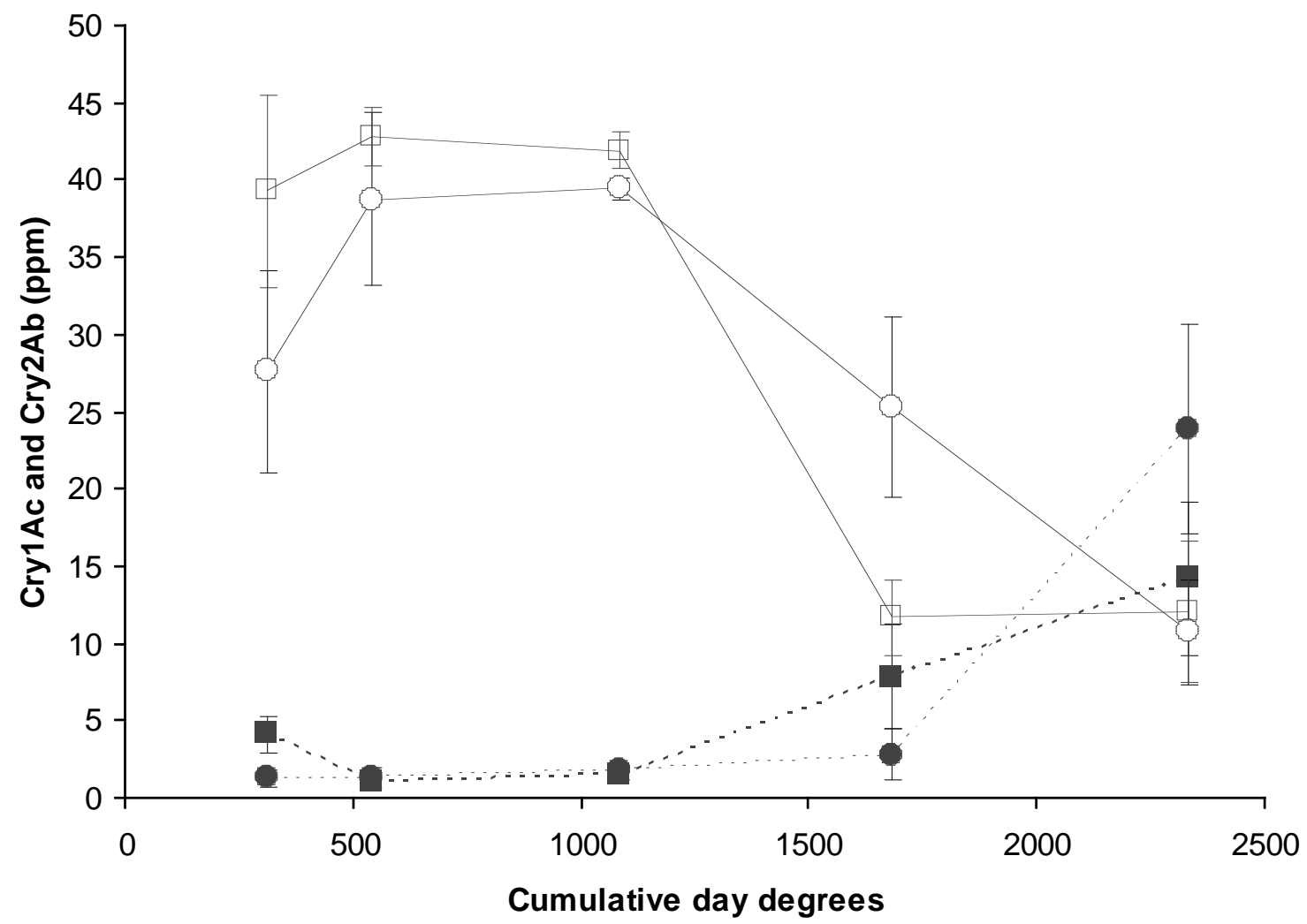

Fig. (4). Seasonal variation in the expression of CrylAc (closed) and Cry $2 A b$ (open) in leaf and flower/square/boll material from field grown Sicot 289B (circles) and 289BR (squares). Means of 4 plants at each sample point are presented with error bars representing the standard error of the means. Time throughout the season is expressed as cumulative day degrees. 
Statistical analysis revealed that time of sampling and tissue type both resulted in significant differences in detected Cry protein levels (main effect for both tests, $P \leq 0.05$ ), but that there was no significant difference in expression of CrylAc or Cry2Ab between 289B and 289BR or any interaction between variety, partitioned tissue and sampling time (in all cases $P>0.10$ ).

\section{Environmental Loading of Cry Proteins}

The mass of Cry proteins incorporated into the soil at the end of the season were estimated from the 193 DAP (7 days post defoliation) sampling, which had mean CrylAc and Cry $2 A b$ levels of $19.1 \mu \mathrm{g} / \mathrm{g}$ and $11.5 \mu \mathrm{g} / \mathrm{g}$, respectively. Plant biomass at this time had a mean of $385.3 \mathrm{~g}$ dry weight per plant with a stand count of 8 plants per metre, which represented 8000 plants in a hectare. The top $15 \mathrm{~cm}$ of field soil, the depth to which the soil was mechanically worked post slashing of the crop, had an averaged bulk density of 1.49 $\mathrm{g} / \mathrm{cm}^{3}$. This data provided an estimate for the soil mass, into which the plants were incorporated at the end of season of $2.24 \times 10^{6} \mathrm{~kg}$. Stands of 12 plants per metre, the industry recommended plant density, were recorded elsewhere on the station and an assessment based on 12 plants per metre was included for comparison (Table 1).

\section{DISCUSSION}

The quantitative CrylAc ELISA method used in the initial investigation of glasshouse versus field material has been used extensively in other work [23] and found to produce highly repeatable results. Our decision to desiccate and grind plant material was made based on existing facilities, the requirement to process both soft and woody plant tissue, and to facilitate the simultaneous throughput of samples in a 96 well format. A preferred method of tissue preparation and storage prior to extraction would have been freeze drying [20], but was not available to us at the time of the experimentation.

Comparison of the roots from glasshouse and field grown plants showed that expression of CrylAc varied with plant growth and environment. The glasshouse material experienced a steady decline in expression as plant age increased. In contrast, our field root material measurements showed that expression levels of CrylAc increased over the season. Several factors may have contributed to these differences, particularly different root architecture. Differences in the physiology of the field and glasshouse root systems could have implications for plant nutrient and water acquisition [24] that could in turn affect CrylAc expression levels [23, 25]. As well as visual differences in the plant root systems, field grown cotton was exposed to prolonged environmental wet and dry periods, several flood irrigations, diurnal temperature fluxes of approximately $20^{\circ} \mathrm{C}$, and repeatedly exposed to insect pest pressures. In contrast, glasshouse plants were watered daily to prevent water stress, experienced diurnal temperature fluxes of only $12^{\circ} \mathrm{C}$, and were not exposed to insect pests.

Analysis of the field grown cotton in the subsequent season permitted further evaluation of CrylAc. The change to the SDI plates facilitated improved analysis of both $C r y$ proteins by adding the ability to quantify $C r y 2 A b$ and removed the use of a CrylAb calibrator for CrylAc assessments, which increased detection levels (direct comparison not shown, see Figs. (1) and (2)). With the change of plates and seasons came a change in the extraction methodology. A ball mill was used to grind the desiccated plant material, in place of the coffee grinder, which provided a much finer and more evenly disrupted material to work on. This change in the extraction methodology was considered to be the major reason behind the increase in CrylAc detected between the 2003/04 and 2004/05 seasons, although changes in plate manufacturers were also made.

Expression of CrylAc increased toward the end of the season in most of the tested tissues (Fig. 2) and when assessed in whole plants (Fig. 3), which is in contrast to some published literature [26]. Possible explanations for this discrepancy are due to the use of field plants, the environmental conditions of the particular season, and season length, which in Australia is around 180 days, but in the United States of America is nearer to 150 days. Our measured increase in CrylAc expression occurred at 137 DAP (Figs 3 and 4), which would correspond to very late season sampling in America, when fruit loads are largely determined, as opposed to a period of continued crop development within the longer Australian season.

In contrast to CrylAc, in most of the tested tissues $C r y 2 A b$ peaked early in the season and then declined after 1000 day degrees (Figs. 2-4). This pattern of expression of Cry $2 A b$ was similar to that reported by Adamczyk et al. (2001) working with DP50 Bollgard ${ }^{\circledR}$ II [26]. Reasons for this decline in $C r y 2 A b$ expression are currently unknown and could be due to either one or a combination of a number of factors. Differences in transformation events and promoters

Table 1. The Cry1Ac and Cry2Ab Levels from Field Grown Cotton Obtained in this Study Compared to Values Available from Previously Reported Studies (Sims and Ream 1997; U.S. EPA. 2002). FW = Fresh Weight, DW = Dry Weight

\begin{tabular}{|c|c|c|c|c|c|c|c|c|c|c|c|}
\hline & \multirow{2}{*}{ Sample Preparation } & \multirow{2}{*}{ Tissue Type } & \multirow{2}{*}{$\begin{array}{l}\text { Plants } \\
\text { Per ha }\end{array}$} & \multicolumn{2}{|c|}{ ug/g Expressed } & \multirow{2}{*}{\multicolumn{2}{|c|}{ Plant Mass }} & \multicolumn{2}{|c|}{ g/ha } & \multicolumn{2}{|c|}{ ug/g Soil } \\
\hline & & & & Cry $1 A c$ & Cry $2 A b$ & & & Cry1Ac & Cry $2 A b$ & CrylAc & Cry $2 A b$ \\
\hline 8 Plants/m & Dehydrated and ground & Partitioned/whole & 80000 & 19.14 & 11.5 & $385.3 \mathrm{~g}$ & DW & 590.0 & 354.5 & 0.263 & 0.158 \\
\hline 12 Plants/m & Dehydrated and ground & Partitioned/whole & 120000 & 19.14 & 11.5 & $385.3 \mathrm{~g}$ & DW & 885.0 & 531.7 & 0.395 & 0.237 \\
\hline BRAD & Not reported & Not reported & 149400 & & & & & 3.56 & & 0.0016 & \\
\hline EPA & Not reported & Not reported & & & & & & 1.44 & & & \\
\hline Sims \& Ream & Fresh leaf & Leaf & 149400 & 34 & & $238 \mathrm{~g}$ & FW & 1174 & & 1.6 & \\
\hline Head et al. & Dry cotton plant & Not reported & 149400 & 20 & & $250 \mathrm{~g}$ & DW & 747 & & 0.65 & \\
\hline
\end{tabular}


could affect transgenic protein stability [25], however, all commercial cotton varieties derived their transgenic material from specific and stable insertion events MON531 [27] for CrylAc and MON15985 [10] for the Cry2Ab. This similarity in the inserted transgenic material suggests that variation in expression levels of Cry proteins is more likely to reflect differences between the parentage of tested lines, plant stress and/or the environmental conditions of the season [28]. Transcriptional regulation and temperature differences have been reported to effect $C r y 1 A c$ expression [7, 29] and could affect $C r y 2 A b$. Whilst purified $C r y 2 A b$ has been reported as temperature stable in water [12], we observed instability of the Corn powder $C r y 2 A b$ standard when freeze/thawed. Onset of higher summer temperatures could also increase expression of heat shock proteins to the detriment of other proteins [28]. Whatever the reason for the decrease in Cry2 $\mathrm{Ab}$ expression, it was common to both the assessed $289 \mathrm{~B}$ and $289 \mathrm{BR}$ cultivars tested $[6,23,30]$.

Cry protein expression data can facilitate the assessment of environmental loading of the Bt proteins from the transgenic plants $[2,18,31]$ and provide information on seasonal expression levels of relevance in continued evolution of insecticidal resistance $[9,32]$. Previous assessments of the cotton plant contribution of Cry proteins to the soil post season have been made [33-35], however, these analyses differed from ours on a number of aspects; (i) the reports dealt solely with CrylAc, (ii) Cry protein levels were not assessed for the whole plant, but predominantly from leaf material, (iii) plant population measures were estimated, and (iv) field incorporation was not based on actual management strategies.

In our study, we estimated an end of season incorporation of $0.26 \mu \mathrm{g} / \mathrm{g}$ soil CrylAc and $0.16 \mu \mathrm{g} / \mathrm{g}$ soil for $C r y 2 A b$, similar to findings of previously published studies [12, 33, 35, 36] (Sims and Ream 1997; U.S. EPA. 2002), but this record presents the first estimate of both CrylAc and Cry $2 A b$ that we are aware of. There are, however, constraints and sources of error even within our estimates. We assumed equal extraction efficiency of both Cry proteins from all plant tissues, but in reality the composition of different tissues and their age is likely to impact on both the readiness by which the proteins are extracted and the content of other substances that could inhibit the ELISA [37-39]. Tissue extraction is clearly important [20], but in the absence of access to freeze drying facilities we opted for a method that permitted extraction of all plant tissues, whether soft or woody. During our experiments we obtained experimental evidence that desiccating and grinding leaf tissues caused a 2.5 increase in the levels of detected $C r y 1 A c$, but reduced levels of $C r y 2 A b$ to 0.4 , when compared to fresh leaf tissue extractions. Field loading of Cry protein through root exudation or plant senescence and degradation was not included in our assessment as there is currently insufficient understanding of the levels of deposition, persistence and degradation of transgenic Cry proteins within soil from these processes $[12,34]$. The amount of root material recovered averaged only 0.093 of the recovered plant dry weight biomass, which although similar to other published data [40] did not represent complete root system recovery. Our expression measurements are for 8 plants per $m$ plant stand and evidence exists that Bt expression is density dependant [18] therefore our estimations for 12 plants per $\mathrm{m}$ plant stand are estimations only.
Much of the work on the expression levels of Bt proteins in BollgardII ${ }^{\circledR}$ cotton has been assessed or inferred from experiments involving (i) transgenic donor material that is rarely grown commercially [13], (ii) plants reared in glasshouse conditions [38], and (iii) field trials of non-commercial varieties often containing Cry constructs that were not commercially released $[35,41,42]$. This study highlights that physiological and environmental differences between glasshouse and field grown cotton have an effect on the expression levels of transgenic Cry proteins.

\section{CONCLUSION}

Analysis of CrylAc protein in glasshouse and field grown cotton suggested that environmental factors contributed to both plant physiology and expression levels of transgenic proteins within roots. Field analysis of whole plants indicated that CrylAc and Cry2Ab, the two transgenic proteins found in Bollgard ${ }^{\circledR}$ II cotton, differ in their expression profiles over the growing season. The ELISA methods used provided reproducible estimates of both proteins from specific standards at levels ranging from 0 to $60 \mathrm{PPB}$ and 0 to $70 \mathrm{PPB}$ for $C r y 1 A c$ and $C r y 2 A b$, respectively, allowing estimates of the amount of Cry protein incorporated back into the soil at the end of the season to be made. These estimates were comparable with previous reports and present an improvement to currently available data due to the assessment of both Cry proteins in all tissues of field grown cotton. The reported values for protein loads are, however, still estimates.

Analysis of the various plant tissues revealed significant differences in expression levels between above and below ground tissues, but that overall plant trends were similar. Differences between partitioned tissues' level of expression, of both $C r y 1 A c$ and $C r y 2 A b$, indicated that there is a requirement to analyse entire plants to improve environmental loading predictions. Our results would imply that assessments based solely on leaf material would under estimate CrylAc expression and overestimate $C r y 2 A b$ expression (Fig. 2). Whilst ELISA is currently the preferred way to interrogate specific protein expression from a range of tissues, there is room to improve the system in terms of standard selection and tissue preparation methodology, and the provision and use of suitable and accurate standards. The outlined discrepancies between results obtained in this study and those presented in others, investigating expression levels in transgenic plants, highlights the need for standardised and reproducible field procedures, and the assessment of transgenic cultivars on a case by case and season by season basis.

\section{ACKNOWLEDGEMENTS}

This work was carried out with the support of CSIRO Divisions of Entomology, Land and Water, and Plant Industries. Financial assistance was obtained from the Cotton Catchment Communities CRC and Cotton Research and Development Corporation funding. Cry protein standards were obtained with the assistance of Stewart Addison (Monsanto, Australia), Ray Akhurst and Bill James (CSIRO Entomology). The technical assistance of Leanne Scott (CSIRO Entomology) is acknowledged.

\section{REFERENCES}

[1] Bennett R, Ismaely Y, Morse S. Explaining contradictory evidence regarding impacts of genetically modified crops in developing coun- 
tries. Varietal performance of transgenic cotton in India. J Agric Sci 2005; 143(1): 35-41.

[2] Bennett R, Ismaely Y, Morse S, Shankar B. Reductions in insecticide use from adoption of Bt cotton in South Africa: impacts on economic performance and toxic load to the environment. J Agric Sci 2005; 142(6): 665-74.

[3] Knox OGG, Constable GA, Pyke B, Gupta VVSR. EnvironmentaliImpact of conventional and Bt insecticidal cotton expressing one and two Cry genes in Australia. Aust J Agric Res 2006; 57(5): 501-9.

[4] Daly JC. Efficacy of Bt cotton plants in Australia: What is going on? 2nd World Cotton Reseacrh Conference: Athens, Greece 1998.

[5] Fan X, Zhao JZ, Fan Y, Shi X. Inhibition of transgenic Bt plants to the growth of cotton bollworm. Plant Prot 2000; 26: 3-5.

[6] Adamczyk JJ Jr, Sumerford DV. Potential factors impacting seasonlong expression of Cry1 Ac in 13 commercial varieties of Bollgard ${ }^{\circledR}$ cotton. J Insect Sci 2008; 1(13): 1-6.

[7] Olsen KM, Daly JC, Holt HE, Finnegan EJ. Season-long variation in expression of Cry1Ac gene and efficacy of Bacillus thuringiensis toxin in transgenic cotton against Helicoverpa armigera (Lepidoptera: Noctuidae). Econ Entomol 2005; 98(3): 1007-17.

[8] Tabashnik B, Dennehy T, CarrièRe Y, Liu YB, Meyer S, Patin A. Resistance management: slowing pest adaptation to transgenic crops. Acta Agric Scand Sec B Plant Soil Sci 2003; 53: 51-6.

[9] Matten SR, Reynolds AH. EPA IRM requirements for Bollgard II cotton. Proceedings of the Beltwide Cotton Conference, Nashville, TN 2003.

[10] Monsanto. Safety assessment of Bollgard II cotton event 15985. 2003. Ref Type: Electronic Citation http://www.monsanto.com/pdf/ products/bollgard_II_pss.pdf

[11] Roush RT. Bt-Transgenic Crops: Just another pretty insecticide or a chance for a new start in resistance management? Pest Sci 1997; 51(3): 328-34.

[12] U.S. EPA. Biopesticide registration action document (Bacillus thuringiensis $\mathrm{Cry} 2 \mathrm{Ab} 2$ protein and its genetic material necessary for its production in cotton.). 2002. Ref Type: Electronic Citation http://www.epa.gov/oppbppd1/biopesticides/ingredients/tech_docs/bra d_006487.pdf

[13] Greenplate JT, Mullins JW, Penn SR, et al. Partial characterization of cotton plants expressing two toxin proteins from Bacillus thuringiensis: relative toxin contribution, toxin interaction, and resistance management. J Appl Entomol 2003; 127(6): 340-7.

[14] Baumgarte S, Tebbe CC. Field Studies on the Environmental Fate of the Crylab Bt-Toxin Produced by Transgenic Maize (Mon810) and its Effect on Bacterial Communities in the Maize Rhizosphere. Mol Ecol 2005; 14(8): 2539-51.

[15] Rui YK, Yi GX, Zhao J, et al. Changes of Bt toxin in the rhizosphere of transgenic Bt cotton and its influence on soil functional bacteria. World J Microbiol Biotechnol 2005; 21(6-7): 1279-84.

[16] Sisterson M, Biggs R, Olson C, Carriere Y, Dennehy T, Tabashnik B. Arthropod abundance and diversity in $\mathrm{Bt}$ and non-Bt cotton fields. Environ Entomol 2004; 33(4): 921-9.

[17] Schuler TH, Denholm I, Jouanin L, Clark SJ, Clark AJ, Poppy GM. Population-scale laboratory studies of the effect of transgenic plants on nontarget insects. Mol Ecol 2001; 10(7): 1845-53.

[18] Saxena D, Stotzky G. Insecticidal toxin from Bacillus thuringiensis is released from roots of transgenic Bt corn in vitro and in situ. FEMS Microbiol Ecol 2000; 33(1): 35-9.

[19] Gupta VVSR, Watson S. Ecological impacts of GM cotton on soil biodiversity. Report for the Australian Government DEWHA. Ref Type: Report CSIRO Land and Water 2004.

[20] Holt HE, Mares C, Akhurst R. Determination of the Cry protein content of Bt transgenic cotton a technical manual for laboratory use. Technical Report CSIRO Division of Entomology 2002; (92).

[21] Knox OGG, Gupta VVSR, Nehl DB, Stiller WN. Constitutive expression of Cry proteins in roots and border cells of transgenic cotton. Euphytica 2007; 154(1-2): 83-90.

[22] Mahon RJ, Olsen KM, Downes S, Addison S. Frequency of Alleles Conferring Resistance to the Bt Toxins Cry1Ac and Cry2Ab in Aus- tralian Populations of Helicoverpa armigera (Lepidoptera: Noctuidae). J Econ Entomol 2007; 100: 1844-53.

[23] Rochester IJ. Effect of genotype, edaphic, environmental conditions, and agronomic practices on Cryl Ac protein expression in transgenic cotton. J Cotton Sci 2006; 10(4): 252-62.

[24] McMichael BL, Quisenberry JE. The impact of the soil environment on the growth of root systems. Environ Exp Botan 1993; 33(1): 53-61.

[25] Adamczyk JJ, Gore J. Varying levels of Cry1 Ac in transgenic Bacillus thuringiensis Berliner (Bt) cotton leaf bioassys. J Agric Urban Entomol 2003; 20(2): 49-53.

[26] Adamczyk JJ. Profling season-long expression of Cry1Ac in 13 commercial varieties of Bollgard cotton: influence of parental background and environmental factors on endotoxin expression levels. In: Dugger P, Richter D, Eds. Proceedings, Beltwide Cotton Conference; Memphis, TN: National Cotton Council 2001; pp: 1420-3.

[27] Monsanto. Safety assessment of Bollgard cotton event 531. 2002. Ref Type: Electronic Citation http://www.monsanto.com/pdf/produ cts/bollgard_pss.pdf

[28] Daly JC. Ecology and resistance management for Bacillus thuringiensis transgenic plants. Biocontrol Sci Technol 1994; 4: 563-71.

[29] Olsen KM, Daly JC, Finnegan EJ, Mahon RJ. Changes in Cry1Ac Bt transgenic cotton in response to two environmental factors: temperature and insect damage. J Econ Entomol 2005; 98(4): 1382-90.

[30] Adamczyk JJ, Adams LC, Hardee DD. Field efficacy and seasonal expression profiles for terminal leaves of single and double Bacillus thuringiensis toxin cotton genotypes. J Econ Entomol 2001; 94(6): 1589-93.

[31] Betz FS, Hammond BG, Fuchs RL. Safety and advantages of Bacillus thuringiensis-protected plants to control insect pests. Regul Toxicol Pharmacol 2000; 32(2): 156-3.

[32] Kranthi KR, Kranthi S, Wanjari RR. Baseline Toxicity of Cryla Toxins to Helicoverpa armigera (Hubner) (Lepidoptera: Noctuidae) in India. Int J Pest Manag 2001; 47(2): 141-5.

[33] Head G, Surber JB, Watson JA, Martin JW, Duan JJ. No detection of Cry1 Ac protein in soil after multiple years of transgenic Bt cotton (Bollgard) use. Commun Ecosyst Ecol 2002; 31(1): 30-6.

[34] EPA regulation of transgenic pesticidal crops and insect resistance managment for B.T. cotton. Memphis, TN. National Cotton Council 2000.

[35] Sims SR, Ream JE. Soil inactivation of the Bacillus thuringiensis Subsp. Kurstaki CryIIa insecticidal protein within transgenic cotton tissue: laboratory microcosm and field studies. J Agric Food Chem 1997; 45(4): 1502-5.

[36] U.S. EPA. Biopesticides Registration Action Document - Bacillus thuringiensis Plant-Incorporated Protectants. 2001. Ref Type: Electronic Citation http://www.epa.gov/oppbppd1/biopesticides/pips/ bt_brad. htm

[37] Sachs ES, Benedict JH, Stelly DM, et al. Expression and segregation of genes encoding CryIA insecticidal proteins in cotton. Crop Sci 1998; 38(1): 1-11.

[38] Greenplate JT. Quantification of Bacillus thuringiensis insect control protein Cry1Ac over time in Bollgard cotton fruit and terminals. J Econ Entomol 1999; 92: 1377-83.

[39] Olsen KM, Daly JC. Plant-Toxin interactions in transgenic Bt cotton and their effect on mortality of Helicoverpa armigera (Lepidoptera: Noctuidae). J Econ Entomol 2000; 93: 1293-9.

[40] Sadras VO. Cotton compensatory growth after loss of reproductive organs as affected by availability of resources and duration of recovery period. Oecologia 1996; 106(4): 432-9.

[41] Sims SR. Host activity spectrum of the CryIIa Bacillus thuringiensis Subsp. Kurstaki protein. effects on lepidoptera, diptera, and non-target arthropods. Southwest Entomologist 1997; 22(4): 395-404.

[42] Wan P, Zhang Y, Wu K, Huang M. Seasonal expression profiles of insecticidal protein and control efficacy against Helicoverpa armigera for Bt cotton in the Yangtze river valley of China. J Econ Entomol 2005; 98(1): 195-201. 